\title{
. (3) . \\ Do audiological classification systems cause more confusion than clarity?
}

\author{
By Dr. Jessica K Edwards
}

In 2018, Barry Wright and colleagues at the Lime Trees Child, Adolescent and Family Unit in York published a paper in the International Journal on Mental Health and Deafness that highlighted the wide variation between classification systems for hearing loss. In this enlightening piece, Wright et al. show that six of the most commonly used classification systems all assign the same descriptive terms to different decibel ( $\mathrm{dBHL}$ ) thresholds (Table 1). For example, there is a staggering $15 \mathrm{dBHL}$ difference in the definition of "profound" deafness between the World Health Organisation's classification system ( $\geq 81)$ and the American Medical Association's system $(\geq 96 \mathrm{dBHL})$. The lack of a single classification system is clearly problematic, not least because it renders intervention studies difficult to interpret and has implications for patient access to services. Going forward, Wright et al. hope that awareness of the differences between these classification systems will improve. Meanwhile work is needed to determine whether a unified system might be helpful. Finally, they explain that practitioners should ideally consider audiological thresholds, as just one part of a holistic assessment, of sensory profiles and quality of life.

\section{Table 1: Different systems of classification}

Reproduced with permission from Wright, B. et al. (2018), The use of audiological classification systems, International Journal on Mental Health and Deafness. 4: 59-64.

\begin{tabular}{|c|c|c|c|c|c|}
\hline Units = db & Mild & Moderate & $\begin{array}{l}\text { Moderate } \\
\text { to Severe }\end{array}$ & Severe & Profound \\
\hline American Medical Association * & $26-40$ & $41-70$ & & $71-95$ & $\geq 96$ \\
\hline $\begin{array}{l}\text { American Speech Language } \\
\text { Hearing Association }\end{array}$ & $26-40$ & $41-55$ & $56-70$ & $71-90$ & $\geq 91$ \\
\hline British Society of Audiology * & $20-40$ & $41-70$ & & $71-95$ & $\geq 96$ \\
\hline $\begin{array}{l}\text { Center for Disease Control } \\
\text { hearing loss criteria for } 2009 \text { and } \\
2010 \text { surveys }\end{array}$ & $21-40$ & $41-70$ & & $71-90$ & $\geq 91$ \\
\hline $\begin{array}{l}\text { Prevention Atlanta } \\
\text { Developmental Disabilities } \\
\text { Surveillance Programme 灹 }\end{array}$ & & $40-64$ & & $65-84$ & $\geq 85$ \\
\hline World Health Organisation $* * * *$ & $26-40$ & $41-60$ & & $61-80$ & $\geq 81$ \\
\hline
\end{tabular}

* Taken in the better ear over 5 frequencies (0.25, 0.5, 1, 2 \& 4 kHertz)

$* *$ Taken as better ear average over 3 frequencies (0.5, 1, 2 Khertz)

**** Taken as better ear average over 4 frequencies (0.5, 1, 2, 4 KHertz) 